\title{
Comparative Studies on the Effects of High Sound Levels on the Haematological Parameters and Antioxidant Levels of Wistar Albino Rats
}

\author{
Chinedu P. Nwuke', Ibeh Bartholomew ${ }^{2}$, Chibuike Daniel Peter ${ }^{1}$ \\ ${ }^{1}$ Michael Okpara University of Agriculture, Umudike, Umuahia Abia State, Nigeria \\ ${ }^{2}$ National Biotechnology Development Agency-NABDA, Abuja, Nigeria \\ Email: chinedu.nwuke@gmail.com
}

How to cite this paper: Nwuke, C.P., Bartholomew, I. and Peter, C.D. (2021) Comparative Studies on the Effects of High Sound Levels on the Haematological Parameters and Antioxidant Levels of Wistar Albino Rats. Open Access Library Journal, 8: e7185.

https://doi.org/10.4236/oalib.1107185

Received: January 26, 2021

Accepted: March 2, 2021

Published: March 5, 2021

Copyright $\odot 2021$ by author(s) and Open Access Library Inc.

This work is licensed under the Creative Commons Attribution International License (CC BY 4.0).

http://creativecommons.org/licenses/by/4.0/

\begin{abstract}
This is a detailed experimental and comparative study evaluating the harmful effects of graded loud noise on hematological and antioxidant in Wistar albino rats. Wistar albino rats were divided into a control group (those kept away from the noise due to a generator set), groups 1 (exposed to varied, 85 - 105 $\mathrm{db}$ levels of loud noise from a generator) and groups 2 (exposed to less, 40 $55 \mathrm{db}$ levels of loud noise from generator set) and exposed to way off fumes from electrical generator sounds at different sound level for 8 hours each day for 28 days. The result indicated that activities and concentrations of the antioxidant enzymes: glutathione peroxidase, catalase and glutathione increased significantly $(\mathrm{p}<0.05)$ when compared with the control group in group 1. There was also an increase in the concentrations of malondialdehyde and hematological parameters (RBC, WBC, PCV, hemoglobin, platelets) among the rats exposed to loud noise from a generator set in group 2, when compared to the control group.
\end{abstract}

\section{Subject Areas}

Drugs \& Devices, Medical Genetics

\section{Keywords}

Noise, Hematology, Oxidative Stress, Inflammation

\section{Introduction}

The lack of constant electric power supply to meet utility usage in developing 
countries like Nigeria has warranted the use of petroleum powered generators to supply electricity. Environmental stressors such as noise and air pollution are becoming more and more important in our industrialized world and pervasive aspect of many modern communities, work environments, which represents a potential novel cardiovascular risk factor, as well as metabolic disease (Igwo-Ezikpe et al., 2014) [1].

Noise pollution is a threat to health and wellbeing, an environmental stressor and nuisance (Smith and Broadbent., 1992) [2]. It is one of the foremost environmental pollutants that has direct effects on human performance (Debasish and Debasish., 2012) [3]. As a common physical nonspecific stressor, it affects the normal functioning of the cardiovascular, endocrine, and immune systems in the body as they manage to balance with the environmental or perceived demands of the individual (Orensen et al., 2011) [4]. Body's inability to handle any overstimulation can result in hazardous stress implications which can affect the immunity and hence causing disease state (Basner and Samuel, 2005) [5]. Its effect on immune function and suppression from the stress load can increase the risk of acquiring diseases. Its damaging effects particularly the productions of free radicals are not limited to the auditory organ. The response to noise may depend on characteristics of the sound, including intensity, frequency, complexity of sound, duration and the meaning of the noise (Abbate et al., 2005 [6]; Ravindran et al., 2005 [7]). Oxidative stress is generated by an imbalance in the number of free radicals produced and the antioxidant system of the body. Reactive oxygen species (ROS) including the members superoxide $\left(\mathrm{O}_{2}^{-}\right)$, hydroxyl radical $(\cdot \mathrm{OH})$, hydrogen peroxide $\left(\mathrm{H}_{2} \mathrm{O}_{2}\right)$, singlet oxygen $\left({ }^{1} \mathrm{O}_{2}\right)$, and nitric oxide (NO) can cause cellular injury or subcellular injury when they are generated in huge amount, or the enzymatic antioxidant defense systems are damaged irreversibly. Additionally, as the non-enzymatic antioxidant defense system is damaged, the same results can be seen in terms of the harmful effects of ROS. Malondialdehyde (MDA), or as a more general term, thiobarbituric acid reactant substances (TBARS) are produced during the attack of the ROS to the cellular and subcellular membrane lipoproteins and polyunsaturated fatty acids (PUFAs) (Esterbauer, 1993) [8]. Studies show significantly $(\mathrm{p}<0.001)$ higher and lower levels of MDA and SOD in the exposed group to noise than the control groups respectively (Seyedtaghi et al., 2020) [9]. Cardiac hemodynamic parameters, which decline immediately under hypoxic conditions, recover during reoxygenation (Liu et al., 2002) [10], but the biochemical and histopathological studies provide a complicated pattern (Freisleben et al., 1991) [11]. Several studies have demonstrated the interdependency of oxidative stress, immune system, and inflammation (Valero et al., 2013 [12], Csillag et al., 2010 [13]). These enzymatic and nonenzymatic antioxidant systems are necessary for sustaining life by maintaining a delicate intracellular redox balance and minimizing undesirable cellular damage caused by ROS (Duračková, 2010) [14]. The cellular population of reacting oxygen species either decreases antioxidant by increasing the activities of the antioxidant enzymes (like catalase, superoxide dismutase and gluta- 
thione peroxidase) or by stopping the activities of ROS-generating enzymes like $\mathrm{NAD}(\mathrm{P}) \mathrm{H}$ oxidase and xanthine oxidase (XO) (Babisch and Kamp, 2009) [15]. Therefore, the study was designed to evaluate the biochemical effects of noise stress on the hematological and antioxidant properties of the exposed Wistar rats.

\section{Materials and Methods}

\subsection{List of Chemicals/Reagents Used (Table 1)}

All the chemicals used in this study were of analytical grades and products.

\subsection{Experimental Animals}

Fifty (50) albino rats of the Wistar strain aged 10 - 12 weeks and weighing 70 $100 \mathrm{~g}$ bred in animal house of the Department of Zoology and Environmental Biology (ZEB), University of Nigeria, Nsukka Enugu State were used for this study. The animals were transported in aluminium cages to Michael Okpara University of Agriculture Umudike. All animals were housed at controlled room temperature of about $27^{\circ} \mathrm{C}-30^{\circ} \mathrm{C}$ with a photoperiod of 12 -hour light and 12-hour dark per day. The animals were fed Vital Growers Mash and water ad libitum and allowed to acclimatize to their environment for 7 days before experimentation.

\subsection{Toxicological Study Design}

The fifty (50) albino rats of the Wistar strain aged 10 - 12 weeks and weighing 70 $-100 \mathrm{~g}$ bred were all fed with Vital growers mash and water, then were randomly grouped into 3 main groups, which consist of a control group, group 1 and group 2. Group 1 (for high sound level of $85 \mathrm{db}-105 \mathrm{db}$ ) and group 2 (low sound level of $40 \mathrm{db}-55 \mathrm{db}$ ) were sub divided into subgroups with five albino

Table 1. List of chemicals and reagents and their manufacturers.

\begin{tabular}{cc}
\hline Reagents/Chemicals & Manufacturer \\
Buffer & Randox Kit, UK \\
Phosphate buffer & Randox Kit, UK \\
$\alpha$-Oxoglutarate & Randox Kit, UK \\
2,4-Dinitrophenylhydrazine & Randox Kit, UK \\
Carbonate buffer pH & Randox Kit, UK \\
Xanthine oxide 0.3 $\mu /$ ml & Randox Kit, UK \\
Sodium hydroxide solution & Randox Kit, UK \\
2-Amino, 2-methly-1-propanol pH 11 (7.9 M) & Randox Kit, UK \\
Na $2_{2}$ PO $_{4}(80 \mathrm{nM})$ & Randox Kit, UK \\
Tris-HCl & Drug House (BDH) Ltd. \\
\end{tabular}


rats and exposed to way off fume from electrical generator sounds at different noise levels for 8 hours each day for 28 days as follows:

Control group: kept away from generator set at noise level less than 30 decibels

Group 1a: Exposed to noise level of 85 decibels

Group 1b: Exposed to noise level of 95 decibels

Group 1c: Exposed to noise level of 105 decibels

Group 1d: Exposed to noise level of above 105 decibels

Group 2a: Exposed to noise level of 55 decibels

Group 2b: Exposed to noise level of 50 decibels

Group 2c: Exposed to noise level of 45 decibels

Group 2d: Exposed to noise level of 40 decibels

Group 2e: Exposed to noise level of below 40 decibels

They were anaesthetized with chloroform, sacrificed by cervical dislocation and blood samples collected through cardiac puncture using $2 \mathrm{ml}$ syringes. Blood samples for biochemical assays were collected in plain tubes and allowed to clot before centrifugation and the sera were separated thereafter and used for the assays, while the blood samples for haematological parameters were collected in EDTA-containing sample bottles and used for the tests.

\subsection{Determination of MDA Concentration}

The concentration of malondialdehyde (MDA) was evaluated in the serum. The method described by Wallin et al. (1993) [16] was used. The principle of the method was based on the spectrophotometric measurement of the colour developed during the reaction of thiobarbituric acid with MDA. The solutions were cooled under tap water and the absorbance was measured with an ultraviolet (UV) spectrophotometer (T80+ UV/Visible Spectrophotometer, PG Instruments Ltd., Leicestershire, United Kingdom) at $532 \mathrm{~nm}$. The concentration of MDA in the samples was calculated by using the absorbance coefficient, MDA-TBA complex $1.56 \times 10^{5} \mathrm{~cm}^{-1} \cdot \mathrm{M}^{-1}$.

\subsection{Assays of the Activities of Serum Antioxidant Enzymes}

Superoxide dismutase activity was assayed by the method of Arthur and Boyne (1985) [17] as contained in Randox kit. Catalase activity was assayed with the Randox kit according to the method described by Sinha (1972) [18]. Glutathione peroxidase (GPx) was measured according to the method of Paglia and Valentine (1967) [19], while the reduced glutathione level was determined by the method of Exner et al. (2000) [20].

\subsection{Hematological Evaluations}

The total white blood cell count was determined by haemocytometry following the method described by Ochei and Kolhatkar (2008) [21]. This method was used for the determination of red blood cells, where, the blood specimen was di- 
luted 1:200 with RBC diluting fluid and cells were counted under high power (40x) objective by using a counting chamber. The number of cells was calculated and reported as the number of red cells $/ \mathrm{mm}^{3}$ of whole blood. The packed cell volume was determined using the microhaematocrit centrifuge (JouanA13 model). The haemoglobin $(\mathrm{Hb})$ concentration was measured spectrophotometrically by cyanomethaemoglobin method. The platelet count was obtained using the haemocytometer.

\subsection{Data Analysis and Statistical Procedures}

Statistical analysis of the data was carried out with SPSS version 22.0 using One Way Analysis of Variance (ANOVA). The statistically analyzed data were reported as Mean \pm SD. Significant difference was accepted at $95 \%$ confidence level of probability i.e. if $\mathrm{p}<0.05$.

\section{Results}

\subsection{Effects of Consumption on Haematological Parameters} (Table 2)

The red blood cell count, white blood cell count, platelets concentration, haemoglobin concentration and packed cell volume in group 1 exposed to high noise level (between $85 \mathrm{db}-105 \mathrm{db}$ ) increased significantly ( $\mathrm{p}<0.05)$ when compared to the control. However red blood cell, platelet and Packed Cell Volume of the Wistar rats in group 2 exposed to low noise level (between $55 \mathrm{db}-40 \mathrm{db}$ ) increased slightly though significantly $(\mathrm{p}<0.05)$ above the control group but not as much as those in group 1 .

\subsection{Effects of Sound Level Exposure on Antioxidant Balance (Table 3)}

The glutathione concentration of the Wistar rats in group1 exposed to high noise

Table 2. Effect of sound level exposure to heamatological parameters.

\begin{tabular}{cccccc}
\hline $\begin{array}{c}\text { Exposed } \\
\text { Groups }\end{array}$ & WBC $\left(\times 10^{9} / \mathrm{L}\right)$ & $\mathrm{RBC}\left(\times 10^{12} / \mathrm{L}\right)$ & $\begin{array}{c}\text { PLATELET } \\
\left(\times 10^{9} / \mathrm{L}\right)\end{array}$ & PCV $(\%)$ & HB $(\mathrm{g} / \mathrm{dL})$ \\
\hline Control & $4.15 \pm 0.74^{\mathrm{d}}$ & $3.09 \pm 0.38^{\mathrm{d}}$ & $195 \pm 0.48^{\mathrm{a}}$ & $36.75 \pm 0.70^{\mathrm{b}}$ & $13.15 \pm 0.08^{\mathrm{a}}$ \\
Group 1a & $5.75 \pm 0.78^{\mathrm{abc}}$ & $3.6 \pm 0.28^{\mathrm{ab}}$ & $254.0 \pm 2.83^{\mathrm{a}}$ & $36.0 \pm 2.83^{\mathrm{b}}$ & $12.83 \pm 0.25^{\mathrm{c}}$ \\
Group 1b & $5.0 \pm 0.28^{\mathrm{a}}$ & $3.95 \pm 0.35^{\mathrm{abc}}$ & $258.5 \pm 2.12^{\mathrm{b}}$ & $40.5 \pm 0.71^{\mathrm{c}}$ & $15.29 \pm 0.86^{\mathrm{d}}$ \\
Group 1c & $5.45 \pm 1.34^{\mathrm{ab}}$ & $4.9 \pm 0.42^{\mathrm{c}}$ & $254.5 \pm 0.71^{\mathrm{b}}$ & $47.0 \pm 1.41^{\mathrm{d}}$ & $16.22 \pm 0.17^{\mathrm{e}}$ \\
Group 1d & $6.65 \pm 0.71^{\mathrm{bcd}}$ & $4.95 \pm 1.06^{\mathrm{c}}$ & $248.5 \pm 2.12^{\mathrm{d}}$ & $48.5 \pm 0.71^{\mathrm{d}}$ & $15.12 \pm 0.17^{\mathrm{d}}$ \\
Group 2a & $7.55 \pm 0.49^{\mathrm{de}}$ & $4.60 \pm 0.28^{\mathrm{bc}}$ & $232.0 \pm 2.82^{\mathrm{c}}$ & $46.0 \pm 0.00^{\mathrm{d}}$ & $15.74 \pm 0.09^{\mathrm{de}}$ \\
Group 2b & $5.8 \pm 0.28^{\mathrm{abc}}$ & $3.4 \pm 0.28^{\mathrm{a}}$ & $219.50 \pm 2.83^{\mathrm{d}}$ & $47.0 \pm 1.41^{\mathrm{d}}$ & $15.51 \pm 0.14^{\mathrm{d}}$ \\
Group 2c & $7.55 \pm 0.49^{\mathrm{de}}$ & $3.6 \pm 0.28^{\mathrm{ab}}$ & $211.50 \pm 6.36^{\mathrm{d}}$ & $35.0 \pm 1.41^{\mathrm{ab}}$ & $11.32 \pm 0.03^{\mathrm{ab}}$ \\
Group 2d & $8.25 \pm 0.21^{\mathrm{e}}$ & $3.25 \pm 0.35^{\mathrm{a}}$ & $222.0 \pm 2.82^{\mathrm{b}}$ & $35.0 \pm 1.41^{\mathrm{ab}}$ & $11.72 \pm 0.04^{\mathrm{b}}$ \\
Group 2e & $7.15 \pm 0.63^{\mathrm{cd}}$ & $3.9 \pm 0.14^{\mathrm{abc}}$ & $202.5 \pm 2.12^{\mathrm{ab}}$ & $32.5 \pm 0.71^{\mathrm{a}}$ & $10.93 \pm 0.04^{\mathrm{a}}$ \\
\hline
\end{tabular}

Values are expressed as Mean \pm Standard Deviation. 
Table 3. Various effect of sound level on pro- and antioxidant balance.

\begin{tabular}{cccccc}
\hline Exposed Groups & GPX (U/mg) & CAT (U/L) & MDA (U/dl) & CRP (U/dl) & GSH (U/dl) \\
\hline Control & $41.75 \pm 0.78^{\mathrm{d}}$ & $2.73 \pm 0.18^{\mathrm{a}}$ & $3.15 \pm 0.23^{\mathrm{c}}$ & $1.23 \pm 0.02^{\mathrm{d}}$ & $2.22 \pm 0.78^{\mathrm{a}}$ \\
Group 1a & $23.9 \pm 0.86^{\mathrm{b}}$ & $3.58 \pm 0.20^{\mathrm{e}}$ & $3.31 \pm 0.23^{\mathrm{a}}$ & $2.41 \pm 0.00^{\mathrm{d}}$ & $3.08 \pm 0.06^{\mathrm{c}}$ \\
Group 1b & $22.7 \pm 0.49^{\mathrm{b}}$ & $3.18 \pm 0.50^{\mathrm{c}}$ & $4.32 \pm 0.04^{\mathrm{d}}$ & $2.75 \pm 0.04^{\mathrm{f}}$ & $3.87 \pm 0.02^{\mathrm{e}}$ \\
Group 1c & $20.28 \pm 0.50^{\mathrm{a}}$ & $4.10 \pm 0.42^{\mathrm{f}}$ & $3.35 \pm 0.13^{\mathrm{a}}$ & $2.52 \pm 0.04^{\mathrm{e}}$ & $3.37 \pm 0.08^{\mathrm{d}}$ \\
Group 1d & $20.03 \pm 0.85^{\mathrm{a}}$ & $3.32 \pm 0.04^{\mathrm{cd}}$ & $3.70 \pm 0.02^{\mathrm{b}}$ & $2.28 \pm 0.02^{\mathrm{c}}$ & $4.91 \pm 0.02^{\mathrm{f}}$ \\
Group 2a & $42.70 \pm 0.45^{\mathrm{d}}$ & $2.49 \pm 0.36^{\mathrm{a}}$ & $4.86 \pm 0.08^{\mathrm{e}}$ & $1.91 \pm 0.02^{\mathrm{b}}$ & $2.77 \pm 0.04^{\mathrm{b}}$ \\
Group 2b & $44.5 \pm 0.56^{\mathrm{e}}$ & $2.91 \pm 0.21^{\mathrm{b}}$ & $3.63 \pm 0.06^{\mathrm{b}}$ & $1.62 \pm 0.02^{\mathrm{a}}$ & $2.31 \pm 0.21^{\mathrm{a}}$ \\
Group 2c & $40.69 \pm 0.59^{\mathrm{c}}$ & $3.16 \pm 0.85^{\mathrm{c}}$ & $3.54 \pm 0.06^{\mathrm{ab}}$ & $1.62 \pm 0.05^{\mathrm{a}}$ & $2.79 \pm 0.12^{\mathrm{b}}$ \\
Group 2d & $45.6 \pm 2.06^{\mathrm{e}}$ & $2.48 \pm 0.04^{\mathrm{a}}$ & $3.67 \pm 0.08^{\mathrm{b}}$ & $1.66 \pm 0.04^{\mathrm{a}}$ & $2.17 \pm 0.08$ \\
Group 2e & $42.1 \pm 0.60^{\mathrm{cd}}$ & $2.62 \pm 0.14^{\mathrm{a}}$ & $4.04 \pm 0.08^{\mathrm{c}}$ & $1.70 \pm 0.07^{\mathrm{a}}$ & $2.57 \pm 0.03^{\mathrm{b}}$ \\
\hline
\end{tabular}

Values are expressed as Mean \pm Standard Deviation.

level (between $85 \mathrm{db}-105 \mathrm{db}$ ) increased significantly $(\mathrm{p}<0.05)$ when compared to the control. However, the glutathione concentration of group 2 exposed to low noise level (between $55 \mathrm{db}-40 \mathrm{db}$ ) increased significantly but not as high as those in group one. Malondialdehyde concentration of the Wistar rats in group1 exposed to high noise level (between $85 \mathrm{db}-105 \mathrm{db}$ ) increased significantly ( $\mathrm{p}<$ $0.05)$ when compared to the control. There was a significant $(\mathrm{p}<0.05)$ increase in the activities of the antioxidant enzymes catalase and glutathione peroxidase in group 1 exposed to high noise level (between $85 \mathrm{db}-105 \mathrm{db}$ ) when compared with the control and group 2, while their group 2 exposed to low noise level (between $55 \mathrm{db}-40 \mathrm{db}$ ) showed a significant $(\mathrm{p}>0.05)$ decrease when compared with the group 1.

\section{Discussion}

In this study the effects of generator noise pollution from a running noisy generator set on certain biochemical parameters were evaluated using Wistar albino rats kept at different positions which is dependent on the measured sound level. The effects of noise pollution at these different sound pressure levels were considered and compared to the control group. This was achieved in two different groups of the animal exposure, in order to know the effects of our parameters at this distinguished sound pressure levels in group one and group two. Noise exposure higher than $90 \mathrm{~dB}$ is considered a source of stress (Wright et al., 2014) [22].

Oxidative stress is a state where there is a significant imbalance between oxidants and antioxidants which can cause cellular damage, dysfunction or death (Gouin et al., 2012) [23]. The body produces more antioxidants that can help cushion the increasing oxidative stress (Messarah et al., 2011) [24]. The glutathione concentration of the Wistar rats in group 1 exposed to high noise level (between $85 \mathrm{db}-105 \mathrm{db}$ ) increased significantly $(\mathrm{p}<0.05)$ when compared to 
the control. Glutathione is a tripeptide that is found in many mammalian tissues and is a very necessary free-radical scavenger (Molina et al., 2016) [25]. Glutathione plays a crucial role in the antioxidant defense system; removing free-radical species, such as hydrogen peroxide and superoxide radicals as well as maintaining membrane protein thiols (Molina et al., 2016) [25]. The significantly increased level of the glutathione shows the body response to cushion the oxidative stress caused by the high noise. However, the glutathione concentration of group 2 exposed to low noise level (between $55 \mathrm{db}-40 \mathrm{db}$ ) increased significantly but not as high as those in group one which obviously shows that the oxidative stress at that sound pressure isn't much.

Lipid peroxidation is an oxidative process where reactive oxygen species and free radicals generated break down lipid molecules, especially the lipids on the cell membrane leading to cell death (Messarah et al., 2011) [24]. Malondialdehyde is one of the byproducts of lipid peroxidation and a good indicator of oxidative stress (Messarah et al., 2011) [24]. The result of our study showed that malondialdehyde concentration of the wistar rats in group 1 exposed to high noise level (between $85 \mathrm{db}-105 \mathrm{db}$ ) increased significantly $(\mathrm{p}<0.05)$ when compared to the control. This indicates that the noise stress at that sound pressure level caused an increased oxidation stress. This result agrees with the result from many studies done on noise effects on lipid peroxidation.

The antioxidative enzyme glutathione peroxidase, catalyzes the conversion of Hydrogen peroxide $\left(\mathrm{H}_{2} \mathrm{O}_{2}\right)$ to water $\left(\mathrm{H}_{2} \mathrm{O}\right)$ by using reduced glutathione $(\mathrm{GSH})$ and reduced NADPH as cofactors (Molina et al., 2016) [25]. Glutathione peroxidase is a major antioxidative enzyme in many tissues and has been speculated to be a major antioxidative mechanism in the brain (Molina et al., 2016) [25]. Also, in the antioxidant system, catalase catalyses two important reactions, firstly it catalyses the conversion of hydrogen peroxide $\left(\mathrm{H}_{2} \mathrm{O}_{2}\right)$ to water and oxygen, also secondly it catalyses the reduction of hydrogen and lipid peroxides which is also an oxidative defense function. This study agrees with other works done in effects of high sound pressure on the antioxidant enzymes. There was a significant $(\mathrm{p}<$ 0.05 ) increase in the activities of the antioxidant enzymes catalase and glutathione peroxidase in group1 exposed to high noise level (between $85 \mathrm{db}-105$ $\mathrm{db}$ ) when compared with the control and group 2, which indicates the action of the antioxidant enzymes in mopping up the generated free radicals, hence cushioning the oxidative stress that is produced from the increased lipid peroxidation and other oxidative mechanisms. Group 2 exposed to low noise level (between $55 \mathrm{db}-40 \mathrm{db}$ ) showed a significant $(\mathrm{p}>0.05)$ decrease when compared with group 1, this reduced activity of the antioxidant enzymes shows a reduced oxidation stress. The activity of the antioxidant enzymes builds up when there is increasing oxidation stress, to cushion the effect of the increasing oxidative stress (Babisch and Kamp, 2009) [15]. The increased level of malondialdehyde and the concomitant increase in glutathione, glutathione peroxidase and the catalase enzyme shows the organism strives to adaptation in the environment 
(Messarah et al., 2011) [24].

Haematological assay suggests the physiological disposition of the Wistar rats. Haematological studies show the physiological responses of an animal to its internal environment (Kurosaki et al., 2015) [26]. Haematological parameters like red blood cell, white blood cell, packed cell volume, hemoglobin etc. have been identified as a good indicator of the immune status of the animal. The results of this study are in accordance with past studies. The hematological parameters of the blood sample from the Wistar rats which include their red blood cell count, white blood cell count, platelets concentration, hemoglobin concentration and packed cell volume in group1 exposed to high noise level (between $85 \mathrm{db}-105$ $\mathrm{db})$ increased significantly $(\mathrm{p}<0.05)$ when compared to the control. This result agrees with the work done by Sabahi and colleagues which they discovered that the number of red blood cells, white blood cells, hemoglobin, and hematocrit of blood cells of mice increases due to noise exposure over time, which is caused due to effects of vibrating sound on the immune system and hence increasing blood parameters (Sabahi and Moradi, 2002) [27]. Also, Litman in his work explained that noise pollution can increase hemoglobin, hematocrit, and red blood cell count in oil refinery workers, while the mechanism of this process remained unclear (Litman et al., 2005) [28]. Also hematological parameter like red blood cell, platelete and packed cell volume of the Wistar rats in group 2 exposed to low noise level (between $55 \mathrm{db}-40 \mathrm{db}$ ) increased slightly though significantly ( $\mathrm{p}$ $<0.05$ ) above the control group but not as much as those in group 1 which shows that the noise level at that sound pressure is not a strong stressor to affect the immune system. Studies have shown that increased serum levels of CRP, the evidence indicates that platelet parameters are markers that reflect a systemic inflammatory response (Taşoğlu et al., 2017 [29]; Akboga et al., 2016 [30]). Chronic inflammation is typically associated with reactive thrombocytosis, induced by the overproduction of pro-inflammatory cytokines, leading to megakaryocytic proliferation (Müller-Newen et al., 2017) [31].

\section{Conclusion}

In conclusion, elevation of MDA level, an indicator of lipid peroxidation associated with a systemic inflammatory response, by noise exposure indicates that there is oxidative stress in the group exposed to noise in the present study. GSH and GSH-Px activities were increased by noise exposure in the noise group. Therefore, these results appear to support the fact that noise might cause damage not only in the ears but also in whole body leading to oxidative stress. Further studies are needed to clarify how MDA, CAT, CRP and GSH-Px changes caused by noise exposure may affect various degrees of damages in the cells.

\section{Conflicts of Interest}

The authors declare no conflicts of interest regarding the publication of this paper. 


\section{References}

[1] Igwo-Ezikpe, M., Awodele, O., Anyakora, C., Ifegwu, C., Owolabi, A. and Oyewale, A. (2014) Exposure to Gasoline Power Generator Exhaust Fume Negatively Affected Hematological, Liver and Kidney Function Parameters in Female Albino Rats. The FASEB Journal, 28, 766.

[2] Smith, A.P. and Broadbent, D.E. (1992) Non-Auditory Effects of Noise at Work: A Review of the Literature. HSE Contract Research Report No. 30, HMSO, London.

[3] Debasish, P. and Debasish, B. (2012) Effect of Road Traffic Noise Pollution on Human Work Efficiency in Government Offices, Private Organizations, and Commercial Business Centres in Agartala City Using Fuzzy Expert System: A Case Study. Advances in Fuzzy Systems, 2012, Article ID: 828593. https://doi.org/10.1155/2012/828593

[4] Orensen, M., Hvidberg, M., Andersen, Z.J., Nordsborg, R.B. and Lillelund, K.G. (2011) Road Traffic Noise and Stroke: A Prospective Cohort Study. European Heart Journal, 32, 737-744. https://doi.org/10.1093/eurheartj/ehq466

[5] Basner, M., Babisch, W., Davis A., Brink, M. and Clark, C. (2014) Auditory and Non-Auditory Effects of Noise on Health. The Lancet, 383, 1325-1332. https://doi.org/10.1016/S0140-6736(13)61613-X

[6] Abbate, C., Concetto, G. and Fortunato, M.O. (2005) Influence of Environmental Factors on the Evolution of Industrial Noise-Induced Hearing Loss. Environmental Monitoring and Assessment, 107, 351-361. https://doi.org/10.1007/s10661-005-3107-1

[7] Ravindran, R., Devi, R.S., Samson, J. and Senthilvelan, M. (2005) Noise-Stress-Induced Brain Neurotransmitter Changes and the Effect of Ocimum sanctum (Linn) Treatment in Albino Rats. Journal of Pharmacological Sciences, 98, 354-360. https://doi.org/10.1254/jphs.FP0050127

[8] Esterbauer, H. (1993) Cytotoxicity and Genotoxicity of Lipidoxidation Products. The American Journal of Clinical Nutrition, 57, 779-785. https://doi.org/10.1093/ajen/57.5.779S

[9] Seyedtaghi, M., Narges, K., Fereshteh, N., Saeid, A., Jamshid, Y., Ramazan, A., et al. (2020) The Effect of Noise and Dust Exposure on Oxidative Stress among Livestock and Poultry Feed Industry Workers. Toxicology and Industrial Health, 36, 908-915. https://doi.org/10.1177/0748233720962253

[10] Liu, Y., Fiskum, G. and Schubert, D. (2002) Generation of Reactive Oxygen Species by the Mitochondrial Electron Transport Chain. Journal of Neurochemistry, 80, 780-787. https://doi.org/10.1046/j.0022-3042.2002.00744.x

[11] Freisleben, H.J., Kriege, H., Clarke, C., Beyersdorf, F. and Zimmer, G. (1991) Hemodynamic and Mitochondrial Parameters during Hypoxia and Reoxygenation in Working Rat Hearts. Arzneimittel \& Forschung, 41, 81-88.

[12] Valero, N., Mosquera, J., Anez, G., Levy, A., Marcucci, R. and Melchor, D.M. (2013) Differential Oxidative Stress Induced by Dengue Virus in Monocytes from Human Neonates, Adult and Elderly Individuals. PLOS ONE, 8, e73221. https://doi.org/10.1371/journal.pone.0073221

[13] Csillag, A., Boldogh, I. and Pazmandi, K. (2010) Pollen-Induced Oxidative Stress Influences Both Innate and Adaptive Immune Responses via Altering Dendritic Cell Functions. Journal of Immunology, 184, 2377-2385.

https://doi.org/10.4049/jimmunol.0803938

[14] Durackova, Z. (2010) Some Current Insights into Oxidative Stress. Physiological 
Research, 59, 459-469. https://doi.org/10.33549/physiolres.931844

[15] Babisch, W. and Kamp, I. (2009) Exposure-Response Relationship of the Association between Aircraft Noise and the Risk of Hypertension. Noise Health, 11, 161-168. https://doi.org/10.4103/1463-1741.53363

[16] Wallin, B., Rosengren, B., Shertzer, H.G. and Camejo, G. (1993) Lipoprotein Oxidation and Measurement of Thiobarbituric Acid Reacting Substances Formation in a Single Microtiter Plate: Its Use for Evaluation of Antioxidants. Analytical Biochemistry, 208, 10-15. https://doi.org/10.1006/abio.1993.1002

[17] Arthur, J.R. and Boyne, R. (1985) Superoxide Dismutase and Glutathione Peroxidase Activities in Neutrophils from Selenium Deficient and Copper Deficient Cattle. Life Sciences, 36, 1569-1575. https://doi.org/10.1016/0024-3205(85)90381-9

[18] Sinha, A.K. (1972) Colorimetric Assay of Catalase. Analytical Biochemistry, 47, 389-394. https://doi.org/10.1016/0003-2697(72)90132-7

[19] Paglia, D.E. and Valentine, W.N. (1967) Studies on the Quantitative and Qualitative Characterization of Erythrocyte Glutathione Peroxidase. Journal of Laboratory and Clinical Medicine, 70, 158-169.

[20] Exner, R., Wessner, B., Manhart, N. and Roth, E. (2000) Therapeutic Potential of Glutathione. Wiener Klinische Wochenschrift, 112, 610-616.

[21] Ochei, J. and Kolhatkar, A. (2008) Medical Laboratory Science, Theory and Practices. Tata McGraw-Hill, New York, 311-347.

[22] Wright, B., Peters, E., Ettinger, U., Kuipers, E. and Kumari, V. (2014) Understanding Noise Stress Induced Cognitive Impairment in Healthy Adults and Its Implications for Schizophrenia. Noise Health, 16, 166-176. https://doi.org/10.4103/1463-1741.134917

[23] Gouin, J.P., Glaser, R., Malarkey, W.B., Beversdorf, D. and Kiecolt-Glaser, J. (2012) Chronic Stress, Daily Stressors, and Circulating Inflammatory Markers. Health Psychology, 31, 264-268. https://doi.org/10.1037/a0025536

[24] Messarah, M., Saoudi, M., Boumendjel, A., Boulakoud, M.S. and El Feki, A. (2011) Oxidative Stress Induced by Thyroid Dysfunction in Rat Erythrocytes and Heart. Environmental Toxicology and Pharmacology, 31, 33-41. https://doi.org/10.1016/j.etap.2010.09.003

[25] Molina, S.J., Miceli, M. and Guelman, L.R. (2016) Noise Exposure and Oxidative Balance in Auditory and Extra Auditory Structures in Adult and Developing Animals. Pharmacological Approaches Aimed to Minimise Its Effects. Pharmaceutical Research, 109, 86-91. https://doi.org/10.1016/j.phrs.2015.11.022

[26] Kurosaki, T., Kometani, K. and Ise, W. (2015) Memory B Cells. Nature Reviews Immunology, 15, 149-159. https://doi.org/10.1038/nri3802

[27] Sabahi, A. and Moradi, I. (2002) The Effects of Noise Exposure on Rat's Hematologic Parameters and Red Cell Indices. Iranian Journal of Medical Sciences, 27, 85-86.

[28] Litman, G.W., Cannon, J.P. and Dishaw, L.J. (2005) Reconstructing Immune Phylogeny: New Perspectives. Nature Reviews Immunology, 5, 866-879.

https://doi.org/10.1038/nri1712

[29] Taşoğlu, Ö., Şahin, A., Karataş, G., Koyuncu, E., Taşoğlu, İ. and Tecimel, O. (2017) Blood Mean Platelet Volume and Platelet Lymphocyte Ratio as New Predictors of Hip Osteoarthritis Severity. Medicine (Baltimore), 96, e6073. https://doi.org/10.1097/MD.0000000000006073

[30] Akboga, M.K., Canpolat, U., Yuksel, M., Yayla, C., Yilmaz, S. and Turak, O. (2016) 
Platelet to Lymphocyte Ratio as a Novel Indicator of Inflammation Is Correlated with the Severity of Metabolic Syndrome: A Single Center Large-Scale Study. Platelets, 27, 178-183. https://doi.org/10.3109/09537104.2015.1064518

[31] Müller-Newen, G., Stope, M.B., Kraus, T. and Ziegler, P. (2017) Development of Platelets during Steady State and Inflammation. Journal of Leukocyte Biology, 101, 1109-1117. https://doi.org/10.1189/jlb.1RU0916-391RR 